\title{
Ozonized oils: a review of its quality control, stability and effectiveness in the treatment of Acne vulgaris
}

\author{
Gabriela Teixeira $^{\mathrm{a}}$, Stacy Ondina ${ }^{\mathrm{a}}$, Alexandre Bella Cruz ${ }^{\mathrm{b}}$, Tania Mari Bellé Bresolin ${ }^{\mathrm{a}, \mathrm{b}^{*}}$
}

\author{
${ }^{a}$ Curso de Biomedicina, 'brograma de Pós-Graduação em Ciências Farmacêuticas, Universidade do Vale do Itajaí, Rua \\ Uruguai, 458, centro Itajaí-SC, Brazil, CEP 80302-902 \\ *Corresponding author: tbresolin@univali.br
}

\begin{abstract}
Acne affects most young people and its topical treatment with antibacterials is associated with increased bacterial resistance to antibiotics and adverse effects. As an alternative, ozone therapy stands out through the application of ozonized oils. The objective of this work was to raise the scientific evidence about the effectiveness in the treatment of acne, in addition to the techniques of characterization and stability of ozonated oils. This is an exploratory, descriptive study with a quantitative approach, based on the analysis of scientific references in a bibliographic review of the expository type, of the last 20 years. Among the selected references, only four manuscripts reporting clinical studies of ozone therapy, with controversial results. Seven articles with the physicochemical characterization of ozonated oils were found. The major part of manuscripts reported the use of sunflower, sesame and olive oil. The more common techniques used to characterize the ozonation process are the peroxide value (PV) and the iodine index $\left(\mathrm{I}_{\mathrm{i}}\right)$, which represents the proportion of unsaturated groups, whose values increase and decrease, respectively with ozonization progress. The viscosity of oils is increased by the formation of polymeric peroxides; the Fourier Transform Infrared spectroscopy (FTIR), which identifies the decrease in the stretch bands $\mathrm{C}=\mathrm{C}$, in addition to ozone formation, monitored by Nuclear Magnetic Resonance (NMR), are also employed. Increased antimicrobial activity has been demonstrated with the ozone level of the oils, but the activity against Cutibacterium acne has not been reported. Only two article reported satisfactory stability for 6 months of refrigerated ozonized oil or kept at room temperature, showing the need for more specific research to support the application of ozonized oils in the treatment of acne and stability data of these products.
\end{abstract}

Keywords: Ozone, topical use, Cutibacterium acne.

https://doi.org/10.22456/2527-2616.113278

\section{Introduction}

Ozone therapy is a technique used for therapeutic purposes through ozone gas $\left(\mathrm{O}_{3}\right)$, which was discovered in 1840 (1). In aesthetics, this procedure has been used through the application of ozonated water, ozonized oil, transcutaneous immersion of gas or bath (bagging) or directly in the form of steam, using high frequency waves) (2). Some of the aesthetic treatments treated with ozone therapy include treatment of localized fat, cellulite, flaccidity, stretch marks, fibrosis, acne, microvessels, skin blemishes, capillary dysfunctions, rejuvenation and dark circles (3). However, such applications are not necessarily scientifically based.

Among the topical applications of $\mathrm{O}_{3}$, stands out the treatment of acne. Acne is characterized by being one of the most prevalent skin diseases affecting about $80 \%$ of individuals aged 11 to 30 years. It is more common during adolescence due to hormonal changes, however, half of them continue to show symptoms in adulthood (4). Among the consequences of this pathology, the damage to the social life of the people affected, especially young people, stands out in the process of social acceptance, compromising selfesteem and body self-acceptance, in addition to social acceptance (5).

The treatment for inflammatory acne is based on topical antibacterial agents, such as tetracycline, clindamycin and erythromycin, with the risk of inducing bacterial resistance (6) and also adverse effects, such as, phototoxicity gastrointestinal disorders, altered renal function, excessive growth of non-susceptible organisms, such as Candida albicans, gastrointestinal disorders, ranging from nausea, vomiting and diarrhea, in addition to liver toxicity, ototoxicity and pancreatitis (7).

From the pharmaceutical point of view, $\mathrm{O}_{3}$ has been used since the 1980s, with its incorporation into formulations, aiming a cleaning and antiseptic effect, destroying pathogens present on the skin and mucous surfaces, as well how, producing derivatives that increase the availability of oxygen in the ischemic system or inflamed tissues, with the additional advantage of improving local metabolism and tissue proliferation, essential for the process of mucous or / and skin scarring $(8,9)$.

In view of the varied applications of ozone, it is of great importance to characterize and evaluate the stability of oils so that they are suitable under the usual storage conditions for commercial purposes. In this context, there are many analytical techniques to characterize these formulations. Therefore, the objective of this work is to carry out a bibliographic review on the subject, with an emphasis on the effectiveness, obtaining, characterization and stability of commercial ozonized oils used in the treatment of acne.

\section{Experimental section}

This manuscript was built from expository bibliographic reviews on the Univali Portal, in Libraries, using Univali's integrated search system, which uses the EBSCO Discovery Service system, which searches the Univali Collection, Portal CAPES, EBSCO, Library A, Saraiva, Vlex, Univali 
Journals Portal, Scielo Books, Scielo Journals, Open Access Directories, International Thesis and Dissertation Repositories, as well as searches were carried out in the Pubmed database, and Google academic. Some references cited in the selected articles were also included in the study. The terms searched in Univali's integrated search system were: "ozone AND acne"; "Ozone AND acne NOT veterinary NOT sanitization NOT disinfection NOT systemic", "acne AND physiopathology"; "(Ozonized oil) AND stability NOT biodiesel NOT petroleum NOT food"; "Ozone AND generation". The following searches were performed at Pubmed: terms "(ozonized oil) AND skin NOT air"; "(Ozonized oil) AND acne"; "(Ozonized oil) AND nuclear magnetic ressonance"; "(Ozonized oil) AND chromatography NOT air". The selection of articles was carried out based on the reading of the tittles of articles, followed by the abstracts, and the articles to be read in full were then selected. The information was then grouped into the following themes: Pathophysiology of acne; Biological effect of ozone and ozonized products on acne; Obtaining ozonated oils; Characterization techniques and stability studies of ozonated oils.

The inclusion criteria adopted were studies related to the last 20 years (2000-2020), published in Portuguese, English and Spanish, which included the pathophysiology of acne, the biological effect of ozone on the skin, more especially in the treatment of acne, the ozone generation, analytical strategies for the characterization of ozonized oils and stability studies of these formulations. In some cases, an older reference was used, mentioned in the selected references.

\section{Results and Discussion}

\section{Pathophysiology of acne}

Acne is the most common inflammatory dermatosis, affecting up to $85 \%$ of the world population aged 11-30 years, and it can be subdivided according to the severity scale, from mild to severe acne, and affects different locations of the body, face to the back (10). Its pathophysiology is multifactorial and complex, and the sequence of events that lead to its development is still not well known. However, it is believed that the first step is the formation of the micromedions (4). It affects the pilosebaceous follicles through processes of hyperkeratinization, sebaceous hypersecretion, microbial colonization, such as by Cutibacterium acnes, formerly called Propionibacterium acnes, and immune mechanisms of inflammation Zaenglein et al (11).

Such pathology can be divided into non-inflammatory when the comedones are not inflamed and inflammatory according to the predominant lesions, thus, it is classified from I to $\mathrm{V}$ according to the severity of the cases (12). Grade I acne is known to be non-inflammatory, also called comedonian. Grades II, III, IV and V are characterized by inflammatory acne. In grade II, there is a predominance of papulo-pustular lesions in addition to comedones. In grade III, nodules and cysts are present. In grade IV, also known as conglobat, there is the presence of several inflammatory nodules, with abscesses and fistulas, which characterizes it as a severe form of the disease. Finally, grade $\mathrm{V}$ is known to be the form of fulminant acne, since it is accompanied by an abrupt onset, with systemic manifestations, ranging from fever, leukocytosis and arthralgia. Therefore, this last degree is the most rare and severe form (12).

The sequence of events most studied in the pathogenesis of acne corresponds to: a) obstruction of the hair follicle (in the infundibulum, the portion from the epidermis to the point where the sebaceous glands discharge), secondary to the abnormal desquamation of follicular keratinocytes; b) increase in sebum production; c) proliferation of anaerobic bacteria $C$. acnes and d) immune and inflammatory reactions triggered by $C$. acnes (13). However, several factors are linked to the appearance of acne, such as nutrition, medications, occupational factors, pollutants, climatic factors and psychosocial and lifestyle factors, which, collectively, are called "exposome" (14).

Acne patients are characterized by increased sebum production, even if this factor is not directly responsible for the development of the lesions (15). Tallow has a marked feature in patients with acne, which is the presence of lipoperoxides, mainly due to squalene peroxidation and a decrease in the level of vitamin $\mathrm{E}$, the main antioxidant in tallow (16).

The genetic factor has a great influence on the origin of this disease, influences hormonal control, follicular hyperkeratinization and sebaceous secretion. It is believed that the increase in sebum production is due to the increase in circulating androgens, greater responsiveness of the gland to androgens or both (11).

Microorganisms also play an important role in the pathogenesis of acne. They colonize the follicles that have a suitable microenvironment for their survival, that is, an anaerobic environment and rich in sebaceous material, thus causing an inflammatory cascade triggered by immune mediators, leading to the rupture of the follicular wall, with lipid, keratinocyte and bacterial antigens leakage. The triggering of this cascade generates the inflammatory process (13).

On the other hand, a higher proportion of the Staphylococcaceae family was detected in patients with acne that could lead to the inhibition of $C$. acnes and decreased production of propionic acid (17), subsequently inducing changes in the skin's $\mathrm{pH}$. These initial events may represent the triggering factors capable of inducing significant changes in the quality of the host's skin, allowing the colonization of the skin by opportunistic bacteria, such as Enterococcus spp. and $S$. aureus which are not present in healthy people (10).

C. acnes is present in the normal skin resident microbiota (12). However, when sebaceous overproduction occurs by the gland, $C$. acnes proliferates favoring the appearance of acne (18). The role of this bacterium in the inflammation of acne, is due to its ingestion by polymorphonuclear leukocytes in the glandular lumen, leading to the release of intracellular hydrolytic enzymes, maintaining its integrity. In addition, the specific antibodies against $C$. acnes interact with them, releasing hydrolytic proteases that act on the infundibular epithelial wall, weakening it and causing 
irritant substances to escape to the underlying dermis, causing the local inflammatory process (19).

The pro-inflammatory agents released by $C$. acnes, include lipases, are capable of degrading triglycerides, and proteases, which damage the follicular wall, triggering inflammation, in addition to the chemotactic factors that recruit CD4 lymphocytes and neutrophils and monocytes (20). Acne is also influenced by diet, which is a predisposing factor for acne. All dairy products and all foods with a high glycemic index must be controlled or interrupted for better control of the condition, since dairy products, for example, contain steroid hormones, which lead to the function of the sebaceous gland (21).

\section{Biological effects of ozone and ozonized products on topical route}

The clinical utility and toxicity of $\mathrm{O}_{3}$ seem to depend on concentration and administration at the appropriate site (1, $22,23)$ and their mechanisms of action are similar to that of a prodrug, as it undergoes reactions giving rise to more active substrates, thus stimulating an endogenous cascade of responses. On the other hand, it differs from a prodrug because it has the ability to interact directly with phospholipids, lipoproteins, cells, envelopes of bacteria and viral capsids (1).

One of the main contraindications for $\mathrm{O}_{3}$ is its inhalation, as this gas significantly increases airway resistance without altering lung compliance or elastic characteristics (22). In addition, direct contact of $\mathrm{O}_{3}$ with the eyes and lungs is contraindicated because of the low antioxidant capacity in these specific locations (24).

$\mathrm{O}_{3}$ is used mainly due to its oxidative activity, being the third strongest oxidative agent, characterized it as a biocidal agent (25).

This inorganic molecule is highly soluble in water, however it is also unstable, due to its nature hindering the obtaining of high concentrations, undergoing transient reactions with itself or with water (1).

Due to this great oxidative power of $\mathrm{O}_{3}$, it reacts instantly with several biomolecules, such as polyunsaturated fatty acids (PUFA) and water, forming the so-called ROSs (Reactive Oxygen Species). This interaction of ozone with biomolecule lipids results in the formation of hydrogen peroxide $\left(\mathrm{H}_{2} \mathrm{O}_{2}\right)$, which is classified as an ROS, and various aldehydes, which are lipid-oxidizing products (PLO) (1, 26). ROSs and PLOs thus have the function of being messengers of ozone, and are responsible for all biochemical and cellular processes that occur onwards. One of the observed actions of $\mathrm{H}_{2} \mathrm{O}_{2}$, which is the main among ROS, would be the positive action of a potentially harmful component. As soon as lipid peroxidation starts, $\mathrm{H}_{2} \mathrm{O}_{2}$ levels increase, generating a concentration gradient that allows this molecule to quickly penetrate the cytoplasm. $\mathrm{H}_{2} \mathrm{O}_{2}$ acts as a signaling molecule capable of activating tyrosine kinases that, in addition to composing insulin receptor enzymes and epidermal growth factor receptors (EGFR), fibroblast (FGFR), platelet derivative (PDGFR) and vascular endothelial (VEGFR), it is responsible for phosphorylating and activating the nuclear factor kappa beta (FNKB), involved in the immune and inflammatory cellular response. FNKB is activated when stimulated by free radicals and stress, cytokines, UV radiation and bacterial and viral antigens. In other words, it acts by stimulating endogenous defense systems, such as increased production of antioxidant enzymes, improved immune response by leukocyte activation and release of growth factors and cytokines involved in tissue repair $(1,26)$.

The principle of ozone therapy is precisely to create a momentary situation of oxidative stress sufficient to activate therapeutic responses in the body (1).

Specifically, in erythrocytes, the entry of ROS slightly decreases the intracellular $\mathrm{pH}$, which increases the availability of oxygen to the tissues. ROS can also increase the levels of 2,3-diphosphoglycerate (2,3-DPG), which decreases the affinity between hemoglobin and oxygen and also acts by increasing its availability. In addition, NO is a ROS that presents vasodilator activity and stimulates angiogenesis, further optimizing oxygen delivery, especially in the proliferative phase of tissue repair (1).

Therefore, the indication for ozone therapy would be appropriate for diseases that cause oxidative stress, such as acne. In diseases where the imbalance between oxidants and antioxidants is established, oxidative stress is constant and becomes chronic. This constancy is broken with ozone therapy, transforming chronic oxidative stress into acute, and the ROS and PLO released increase the activation of the erythroid nuclear factor 2 (Nrf2), responsible for stimulating the enzymatic and non-enzymatic antioxidant systems. However, the treatment should be carried out with caution, using the lowest initial dose and gradually increasing so that the process aggravation is transient and reversible $(1,26)$.

The popularization of the topical use of ozone therapy has extended to the clinical treatment of acute and chronic infectious diseases, in addition to aesthetic treatments, first and second degree burns, psoriasis, herpes zoster and in the treatment of difficult to heal wounds, such as the diabetic foot (27). The application of ozonized olive oil to wounds increased the expression of growth factors (PDGF, TCF- $\beta$ and VEGF) and promoted the synthesis of collagen and the proliferation of fibroblasts (28), as well as stimulated the development of inflammatory responses, such as vasodilation and swelling (29).

Topical application can be done using water, oil or ozonized creams. According to Bocci (30), a physician specialized in respiratory diseases and hematology, emeritus professor of physiology at the University of Siena (Italy) and one of the promoters of ozone therapy, the application of topical ozone has an antiseptic and stimulating healing action since it promotes proliferation and remodeling of tissue cells. In the case of topical use, for wound healing a guide for the safe use of low ozone doses was published (31). In this guide., the authors suggest concentrations of $10-25 \mu \mathrm{g} / \mathrm{mL}$. In the case of acne, this study indicates the route of administration would be autohemotherapy with $10-20 \mu \mathrm{g} / \mathrm{mL}, 10 \mathrm{~mL}$, 100-200 $\mu \mathrm{g} \mathrm{O}_{3}, 1-2$ times a week.

Zeng and $\mathrm{Lu}$ (32) reported the use of ozonated oils in the treatment of scaly erythema, recovery of wounds and skin ulcers, and argue that the oil itself acts as a moisturizer and 
protector particularly for those patients with impaired skin barrier function.

\section{Ozone application in acne treatment}

In the present research, articles related to the dermal application of ozone were found in the treatment of inflammation, proliferation and tissue remodeling, but without an elucidated mechanism of action. Only four references from clinical studies were identified using ozone therapy in the treatment of acne, one of them being published in the period prior to 20 years proposed in the present study, which was included, due to the lack of clinical studies. In this study (33), a clinical study was carried out, performed on the forehead of 16 male people in 7 consecutive days of ozone therapy with an instrument of commercial use that generates ozone, in which, before and at the end of the treatment period, the lipids on the skin surface were analyzed using thin layer chromatography. In this study, the authors observed that there was no decrease in free fatty acids by this therapy. As a result of this finding, the authors conclude that there was no effect on $C$. acnes and other lipase-releasing microorganisms through the use of ozone therapy (33). However, the authors were based on the correlation between the decrease in free fatty acids, not observed in this study, and the absence of antimicrobial action of $\mathrm{O}_{3}$ against $C$. acnes and such negative results may be due to the way in which $\mathrm{O}_{3}$ is applied.

Nikulin et al. (34) applied subcutaneous injections of the $\mathrm{O}_{3} / \mathrm{O}_{2}$ mixture $(300,5,000$ and $10,000 \mu \mathrm{g} / \mathrm{L}, 15 \mathrm{~mL})$ at or around the acne lesions with a microsyringe, in a group of 13 patients ( 9 men and 4 women) aged 14-29 years, who had had acne for 4.5 years on average. The authors evaluated the lipid peroxidation index and the antioxidant system (conjugated plasma and erythromic dienes, malonic dialdehyde, glutathione reductase) in the patients 'blood and concluded that ozone therapy affected the patients' antioxidant system compared to the control group, suggesting that ozone therapy can be an effective method for managing rosacea and acne.

Teodoro et al. (35) analyzed the use of High Frequency (HF) as an electrothermotherapeutic resource that uses alternating currents, in which the gases argon, neon and xenon, when in contact with the oxygen in the air, transform into ozone, commonly used during skin cleaning procedure in aesthetics clinics, indicated for the treatment of acne. These authors found no effect of HF on the reduction of acne lesions in the treated group when compared to the control group, which received only a skin cleansing treatment, although both groups reported an improvement in quality of life and a high level of satisfaction. The authors suggest avoiding the use of products that may interfere with the skin healing process in future studies, since the skin cleaning procedure used facial tonic lotion with herbs and propolis and emollient triethanolamine lotion, with cotton occlusion, for $15 \mathrm{~min}$. In the treated group, ozone vapor was applied together with this last stage of the procedure. At the end, a soothing linden gel was used.

In another clinical study (36), HF was applied together with a skin cleansing treatment in 25 volunteers with grade 2 acne, all of whom reported improvement in the inflammatory condition caused by acne and even improvement in hydration, nutrition, texture and appearance of the skin. However, the authors did not include a control group in the study, which makes the study's conclusions unfeasible, as observed in Teodoro et al. (35).

Ozone therapy, applied to different routes of administration in a young man with a report of chronic conglobate acne, with the presence of large drainage cysts, numerous and painful in the trunk, groin and neck, lasting ten years refractory to the use of antibiotics resulted in a reduction in the number of daily injuries, reduction of pain, reduction of drainage of the injury, decrease in the resolution of the injury (37). In this report, the author used topical ozonized oil, whole body bag with ozone in topical, intralesional form and ozone autohemotherapy, which does not allow inferring about which pathway was responsible for the improvement of the patient's condition. Therefore, the use of ozone in the treatment of acne remains controversial, as the literature lacks controlled studies, as well as without the use of other strategies that may compromise the analysis of the effectiveness of ozone therapy, such as the use of auxiliary treatments in studies.

\section{Methods of obtaining ozonated oils}

For the preparation of ozonated oils, it is necessary to obtain ozone first. The $\mathrm{O}_{3}$ used in ozone therapy is produced from pure $\mathrm{O}_{2}$ for medical use (38) which is done through different systems. Among them, the most popular is the corona discharge system, for its ease of handling and a moderate to high ozone rate, through the application of high voltages (5$13 \mathrm{mV}$ ) (39).

After obtaining $\mathrm{O}_{3}$, the next step is to obtain the ozonated oil. For this process, you can use different oils, from sesame oil to sunflower or coconut oils. Chagas and Mira (40) produced the ozonized oil through an ozone generator, with a concentration of $20 \mu \mathrm{g} / \mathrm{mL}$. The oxygen source used was regulated in a precision flow meter, and the ozone was transported by a silicone hose to a sterile glass that had 40 $\mathrm{mL}$ of sunflower oil and $5 \mathrm{ml}$ of water. The ozonation time was $20 \mathrm{~min}$. After that time, the oil was placed in a $60 \mathrm{~mL}$ syringe, and left to rest for the water and oil to decant, being kept at a temperature of $8{ }^{\circ} \mathrm{C}$. After being separated, the oil was placed in a sterile container and also kept at $8{ }^{\circ} \mathrm{C}$.

Gaseous ozone reacts chemically with unsaturated substrate leading mainly to cyclic ozonized species (9). This mechanism is known as the Criegee reaction, in which $\mathrm{O}_{3}$ acts on an unsaturated bond to form an initial, unstable primary ozonide, which decomposes quickly and forms a zwitterion and a carbonyl fragment that can combine to generate cyclic trioxolane compounds (Figure 1), in anhydrous environments. Also it can combine to a series of aldehydes and peroxides (41), such as hydroperoxides, ozonates, aldehydes, peroxides, diperoxides and poliperoxides and these oxygenated compounds may also be responsible for the wide biological activity of ozonized vegetable oils (42). 
Figure 1. Scheme of the $\mathrm{O}_{3}$ reaction with unsaturated substrates (Criegee reaction)

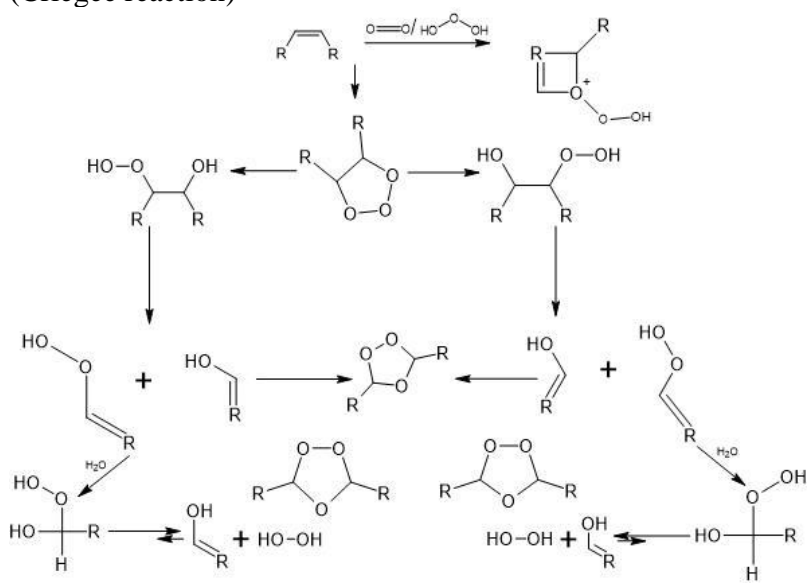

The yield of oxygenated compounds from unsaturated oils depends on the reaction conditions, such as the type of medium where the reaction takes place, the presence of additives, the reaction temperature, the type of reactor, the stirring of the reaction mixture, the doses of ozone applied, among other factors (42).

Rensi et al. (6) reported obtaining ozonized oils using sunflower and coconut oils. Ozone was first produced by the corona system and $\mathrm{O}_{2}$ was supplied via an oxygen cylinder. Ozone was placed in a diffuser, thus generating 2 ppm. Sunflower oil $(1 \mathrm{~L})$ was exposed to $\mathrm{O}_{3}$, directly through a diffuser, for a period of $6 \mathrm{~h}$, while coconut oil (1 L) was ozonated for $10 \mathrm{~h}$. Both at a controlled temperature of $25^{\circ} \mathrm{C}$.

Another method of obtaining ozonized oils was made using sesame oil. According to Valacchi et al. (43), a mixture of ozone with oxygen was made, which bubbled for different moments in Drechsel bottles, which contained $40 \mathrm{~mL}$ of sesame oil, which led to different amounts of ozone. The ozone flow was kept constant at $1.5 \mathrm{~L}$ per minute in all experiments, and the $\mathrm{O}_{3}$ concentration was $45 \mathrm{mg} / \mathrm{L}$.

There are several patents deposited and issued on topical anti-infectious use of ozone: i) in gaseous form; ii) after saturation of gaseous ozone from aqueous, non-greasy pharmaceutical solvents and vehicles; iii) where ozone gas reacts chemically with unsaturated substrates leading to therapeutically active ozonated derivatives (8). Direct ozonation of vegetable oils with unsaturated fatty acids leads to the formation of 1,2,4-trioxolane, the active form of ozone in these substrates (32).

Only from the 2000s onwards that knowledge of how to manage ozone reactivity was consolidated, precisely measuring its concentration and permanently incorporating gas into triglycerides where ozone gas reacts chemically with unsaturated substrates leading to therapeutically active ozonation (44). These authors address the stability and effectiveness of ozonated oils and suggest the best strategies for obtaining products with the best characteristics.

\section{Characterization techniques and stability studies of ozonated oils}

Vegetable oil ozonides are liquid or semi-solid compounds at room temperature and are relatively stable for commercial use under the usual storage conditions (9). However, the photoinstability of the ozonide of glycerol esters should be considered due to the fact that zwitterion undergoes dimerization and formation of a diperoxide derivative in the presence of light. In addition, moisture can also facilitate the breakdown of ozone based on glycerol oil, releasing $\mathrm{O}_{2}$ which also oxidizes the olefinic bonds opened by $\mathrm{O}_{3}$, breaking the long biradical Criegee chain (Figure 1). This species is highly energized and can decompose over a series of different reaction pathways, among which the formation of aldehydes is prevalent (45) resulting in a rancid and unpleasant odor (9).

The quality of ozonized derivatives depends on parameters that involve the configuration of the reactors and their efficiency in the generation of $\mathrm{O}_{3}$, the reaction time, the amount of substance to be ozonized, in addition to the presence of water and/or catalysts (9).

In our research, only seven articles were identified approaching the characterization of ozonated oils, in the studied period. The principal applied techniques for its characterization are shown in Figure 2 and Table 1.

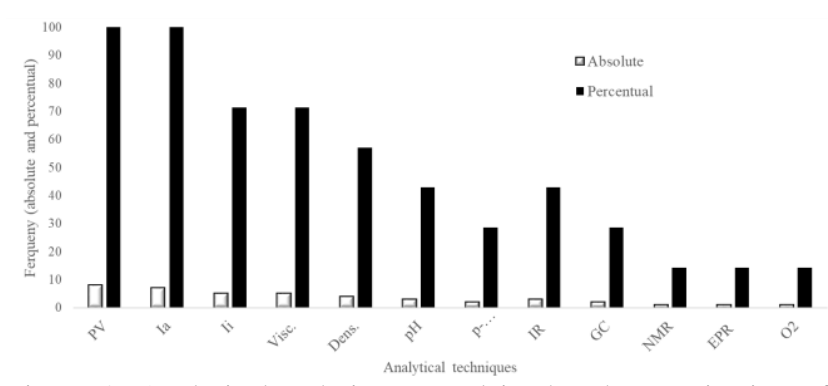

Figure 2. Analytical techniques used in the characterization of ozonized oils.

Analytical methods such as index or value of peroxide (PV), index of acidity $\left(\mathrm{I}_{\mathrm{a}}\right)$, index of iodine $\left(\mathrm{I}_{\mathrm{i}}\right)$ and viscosity were the most used to monitor the ozonation process and to determine the quality of ozonized vegetable oils (Figure 2). These techniques are reported as the choice of this characterization (46). Ferrous oxidation in orange xylenol (FOX) is also used to measure hydroperoxides in edible and ozonized sunflower oils (47), although the analysis most used to measure hydroperoxidation is based on gas chromatography methods (48). 
Olive and Flow of $30 \mathrm{~L} / \mathrm{h}, 80 \mathrm{~mL}$ of oil, and $8 \mathrm{PV}$, Ia, Ii, viscosity, content of The values of PV and Ia, increased with the formation of $\mathrm{O}_{3}$, in both oils,

Sunflower (sample 1) and $246.8 \mathrm{mg} / \mathrm{g}$ (sample 2) antimicrobial activity against $S$. content decreased; due to the increase in viscosity the Ii was not properly in sunflower oil and 34.9 (sample 1) aureus, E. Coli and P. aeruginosa measured; the viscosity value reached in sample 1 was $160 \mathrm{mPas}$, while and $177 \mathrm{mg} /$ (sample 2) in olive oil; corresponding to $\mathrm{PV}$ of about 700 sample 2 solidified completely; In sample 1, the PV increased to $34.9 \mathrm{mg} / \mathrm{g}$. While Ia had a slight increase of $0.28 \mathrm{mg} \mathrm{KOH} / \mathrm{g}$; In sample 2, Ia increased 800 milliequivalents $/ \mathrm{kg}$, for 8.05 and $5.73 \mathrm{~h}$ for sunflower and olive oil, respectively to $17.3 \mathrm{mg} \mathrm{KOH} / \mathrm{g}$, representing an increase of 6.4 times in relation to sample 1; The Ii was 0 in sample 2; both oils showed similar antimicrobial activity, being higher with the increased with the VP, except for P. aeruginosa, whose MIC was higher in the lower VP for sunflower oil.

Sesame $\mathrm{O}_{2}$, flow rate of $1.5 \mathrm{~L} / \mathrm{min}$ and $\mathrm{O}_{3}$ FT IR, $\mathrm{H}^{1}$ and $\mathrm{C}^{13} \mathrm{NMR}$, Ii, Ia, VP, In FTIR the intensity of the bands corresponding to the double bond concentration of $55 \mathrm{mg} / \mathrm{L} ; 40 \mathrm{~mL}$ of viscosity decreased and the band that identifies the formation of ozonide increased in oil, $15-120 \mathrm{~min}$ corresponding to relation to the time of ozone treatment; In NMR, the characteristic signs of about 1,240-9,900 $\mathrm{mg}$ of $\mathrm{O}_{3}$ dose. ozone formation were identified; The Ii decreased with increasing $\mathrm{O}_{3}$ dose (113.65 - 13.39); PV and Ia increased; the viscosity of the samples increased with the dose of $\mathrm{O}_{3}$.

Sesame Medical $\mathrm{O}_{3} / \mathrm{O}_{2}$ mixture at $45 \mathrm{mg} \mathrm{L}$ VP, Ii, viscosity, $\mathrm{C}^{13}$ and $\mathrm{H}^{1} \mathrm{NMR}$ was bubbled, flow $1.5 \mathrm{~L} / \mathrm{min}$, in

The samples show an increase in VP and viscosity values in relation to the time of ozonation. Demonstrated a linear relationship between the integrals of the signals corresponding to the protons which show resonance at 5.29 and $1.97 \mathrm{ppm}$ in $\mathrm{C} 13 \mathrm{NMR}$, or 5.11-5.08 ppm in $\mathrm{H}^{1} \mathrm{NMR}$ with the decrease in double bonds (Ii) and the increase in the value of peroxides (VP); an exponential relationship of viscosity with the integral areas of NMR related to the disappearance of double bond signals

Sunflower $\mathrm{O}_{2}: 75 \mathrm{mg} / \mathrm{L}$ or air: $36 \mathrm{mg} / \mathrm{L}$, duraing $\mathrm{PV}$, Ia, Ii, density, viscosity, GC, The values of VP, Ia, density increased with the formation of $\mathrm{O}_{3}$ (both with oil (15 and $120 \mathrm{~min}$, with doses of 0 $202.5 \mathrm{mg} \mathrm{O} / \mathrm{g}$ oil, corresponding to about 0-8100 $\mathrm{mg} \mathrm{O}$.

$\mathrm{PV}$, Ia, Ii, density, viscosity, GC, The values of VP, Ia, density increased with the formation of $\mathrm{O}_{3}$ (both with
elemental oxygen analysis, EPR, medicinal $\mathrm{O}_{2}$ and with air), showing a linear relationship $\left(r^{2}>0.99\right)$; II and antimicrobial activity against $S$. the content of unsaturated fatty acids decreased with ozonation with both aureus, E. Coli and $P$ aeruginosa

sources, viscosity increased due to polymerization, forming polymeric peroxides; absence of signs of organic free radicals by EPR, proving the absence of free radicals in ozonized oil. Ozonized oil was obtained with VP of $600-700 \mathrm{mEq} / \mathrm{kg}$, for 5-8 h, with medicinal $\mathrm{O}_{2}$ and air, respectively and 0.703 moles of double bonds were consumed at different reaction times. The oil with $658 \mathrm{mEq} / \mathrm{kg}$, obtained with $\mathrm{O}_{2}$, showed the lowest MIC $(4.75$ $\mathrm{mg} / \mathrm{mL}$ ) against $S$. aureus, $9.5 \mathrm{~m} \mathrm{~mL}$ against $E$. coli and $19 \mathrm{mg} / \mathrm{mL}$ against P. aeruginosa.

Cosmetics Medical grade $\mathrm{O}_{2}$ was bubbled in oil VP (reaction with $\mathrm{KI}$ for $16 \mathrm{~h}$ at $25^{\circ} \mathrm{C}$ Comparing the NMR spectra recorded at different current reaction times, it containing (60 samples of Neozone $4000 \AA)$ and in the dark for cosmetics and after 0.5 , is possible to observe that the integrals of the characteristic signals of the ozonized in cosmetics (cream 1 and 2, massage 2,6 and $16 \mathrm{~h}$ for oil), density, NMR ozonide functions gradually decreased with the reaction time: after $16 \mathrm{~h}$ the (azone sunflower oil oil 1 and 2, ointment 1 and 2). For spectroscopy (after 0.5, 2, 6 and $16 \mathrm{~h}$ KI reaction can be considered complete, since the ozone signals disappear; stability, the oil and cosmetics of reaction with KI), density and being that saturated and unsaturated carboxylic acids, in addition to samples were separated into 3 groups, GC/MS. $\quad$ aldehydes are the main products (determined by GC); The PV of the 
${ }^{\circ} \mathrm{C}, 25{ }^{\circ} \mathrm{C}$ and $40{ }^{\circ} \mathrm{C}$, with triplicate analyzes at zero time, $30,60,90,180$ and 360 days. of reaction with KI, respectively; There was a correlation $\left(r^{2}=0.95\right)$ between the peroxide values and the oil density, due to the saturation of $\mathrm{C}$ $=\mathrm{C}$ double bonds in oils treated with ozone, which determines an increase in oil density; The initial PV shows that some cosmetics have slightly higher PVs (10-20\%) than expected if we consider the percentage of ozonized oil; All samples showed satisfactory stability for at least six months, if refrigerated or kept at room temperature, whereas samples stored at $40{ }^{\circ} \mathrm{C}$ or longer, showed a significant decrease in ozone content.

Baru oil, Medical grade $\mathrm{O}_{2}$, flow $1 \mathrm{~L} / \mathrm{min}$., The $\mathrm{Ia}$, Ii, VP, antimicrobial activity $(P$. The bands of double bonds $\mathrm{C}=\mathrm{C}$ decreased with the reaction time and a sunflower $\quad \mathrm{O}_{2} / \mathrm{O}_{3}$ mixture, was bubbled into 200 aeruginosa, E. faecalis and $S$ aureus), new band of C-O of the ozonides by FT-IR appeared, the bands of aldehyde and flaxseed. $\mathrm{mL}$ of vegetable oil at $25^{\circ} \mathrm{C}$ for 6,12 , IR and NMR spectroscopy, disappeared in the ozonized oils; After $24 \mathrm{~h}$ of reaction, the NMR spectra 24, and $36 \mathrm{~h}$. For sunflower oil the cytotoxicity and antitumor activity. indicated the formation of ozonates; the Ia increased as reaction time, due mixture of oil and water $(9 \% \mathrm{v} / \mathrm{v})$ was bubbled with $\mathrm{N}_{2}$ for 5 min and stored at $2-8{ }^{\circ} \mathrm{C}$. to the saturation of the ozonated oil, and the $\mathrm{O} 3$ can react with aldehydes, forming carboxylic acids, especially in the oil formed with sunflower oil; The Ii was $175.14,114.15$ and $89.4 / 100 \mathrm{~g}$ of flaxseed, sunflower and baru oil, respectively, due to the content of unsaturated fatty acids in these samples; the PV increased with the reaction time and was $1933.1 \mathrm{mEq} / \mathrm{kg}$ for the hydrogel; ozonized oils showed antimicrobial activity against Gram positive and Gram negative, and Oleogel showed greater activity against multiresistant clinical strains of E. faecalis and S. aureus; were potentially active against neoplastic cell lines and did not show cytotoxic activity against murine $\mathrm{NIH} / 3 \mathrm{~T} 3$ fibroblasts.

Olive oil Ozone device that produces $95 \%$ O2 $\mathrm{Ia}, \mathrm{Ii}, \mathrm{VP}, \mathrm{p}$-anisidine value, $\mathrm{pH}$, The VP was similar in the two oil samples (1 and 2), between 370 to 392 and $5 \% \mathrm{O}_{3}$ mixture was used to viscosity. $\quad \mathrm{mmol}(\mathrm{mEq} / \mathrm{kg})$, while in the ozonized oil samples these values increased to 1053 and $1352 \mathrm{mmol}$. The Ia in sample 1 was 0.7281 , and 2.0079 , in $\mathrm{O}_{3} / \mathrm{min}$, at $18-20^{\circ} \mathrm{C}$ (1) 8.9951 and 8.4948 respectively. The Ii in olive oils varied from 64.8067 to 62.8731 , while in ozonized samples these values decreased to 2.2040 and 4.3750 . panisidine was 0.155 and $0.100 \mathrm{mmol} / \mathrm{g}$, in olive oil 1 and 2 , respectively. In ozonized oils these values increased to 0.516 and 0.738 , respectively. The viscosity was $81.7-85.5 \mathrm{cP}$ in oils, whereas in ozonized oils these values increased to 1000 and $1630 \mathrm{cP}$. The $\mathrm{pH}$ of the oils was 4.7 and 4.4 , respectively, while in the ozonized samples they decreased to 2.1 and 1.3 .

Sunflower oil Ozone was generated by a Triogen Ia, VP, antimicrobial activity The VP and Ia showed decrease and increase, respectively, in samples kept device (OZAT-CFS1, Ozonia, (Streptococcus uberis), IR and GC Suisse) supplied with $\mathrm{O}_{2}$. An amount of $50 \mathrm{~g}$ of oil and $5 \mathrm{~g}$ of ultra-pure water was placed in a reactor. 65 $\mathrm{mg} / \mathrm{L}$ of $\mathrm{O}_{3} / \mathrm{min}$ at a flow rate of 30 $\mathrm{L} / \mathrm{h}$ of $\mathrm{O}_{3}$, for $4 \mathrm{~h}$, at $27^{\circ} \mathrm{C}$. at $-20{ }^{\circ} \mathrm{C}$ and $+4{ }^{\circ} \mathrm{C}$ remained stable over 1 year. However, the degraded samples showed be still active against Streptococcus uberis, probably due to the presence of ozonides, nonanoic and azelaic acids, these laters compounds increased over time especially at higher storage temperatures. The increase in concentration of the acids compensates for the disappearance of ozonides. 
The PV is the amount of peroxides calculated as milliequivalents (mEq) of active oxygen in $1000 \mathrm{~g}$ of oil sample. PV is commonly determined by iodometric techniques, given the ability of peroxide compounds to oxidize iodide to iodine (53). It is determined by reacting oil peroxides with $\mathrm{KI}$ in medium acidic medium. After such a reaction, the iodine formed is then titrated with $\mathrm{Na}_{2} \mathrm{~S}_{2} \mathrm{O}_{3}$ (55). Ozonization efficiency $(\mathrm{OE} \%)$ can be calculated from the PV, since it represents the proportion\% of the amount of peroxidation due to the ozonation process, to the amount of total ozone applied to the system (9).

According to the Brazilian Pharmacopoeia (56), the PV can be determined as follows: After accurately weighing about $5 \mathrm{~g}$ of the sample, it should be transferred to a $250 \mathrm{~mL}$ conical flask. It is necessary to add $30 \mathrm{ml}$ of a mixture of glacial acetic acid and chloroform (3:2), shake and add 0.5 $\mathrm{mL}$ of saturated potassium iodide solution. Shake for one minute and add an additional $30 \mathrm{~mL}$ of water. Titrate slowly with $0.01 \mathrm{M} \mathrm{SV} \mathrm{Na} \mathrm{S}_{2} \mathrm{O}$, under constant agitation, until the yellow color disappears Add $5 \mathrm{~mL}$ of starch and continue the titration, under vigorous stirring, until the blue color disappears $\left(\mathrm{n}_{1}, \mathrm{~mL}\right.$ of titrant). Perform the blank test (the volume spent on the blank should not exceed $0.1 \mathrm{~mL} ; n_{2}$, $\mathrm{mL}$ of titrant). The PV should then be calculated using equation 1:

$$
V p=10 \frac{\left(n_{1}-n_{2}\right)}{M} \quad \text { Equation } 1
$$

As some materials have shown a high PV, attributed to the slow reactivity of the iodide with dialkylperoxides Zanardi et al. (50) modified the conditions recommended in the European Pharmacopea, such as temperature and reaction time, among others. Using $2 \mathrm{~g}$ of oil sample, they added 3 $\mathrm{mL}$ of saturated KI solution, after mixing a mixture of glacial acetic acid and cloform (3:2). The reflux was kept at $60{ }^{\circ} \mathrm{C}$, for $0-180 \mathrm{~min}$ in samples submitted to different ozonation times (15-120 min), then cooling and adding 25 $\mathrm{mL}$ of water, for later titration and determination of PV. The samples were simultaneously analyzed by FTIR and NMR. According to these authors, the determination of PV, according to the European Pharmacopoeia (57), leads to an underestimation of the reaction of $\mathrm{O}_{3}$ with unsaturated substrates. They demonstrated that PV increases considerably after $10 \mathrm{~min}$ of reflux, corresponding to a decrease in the $\mathrm{CO}$ stretch band and found a plateau after $120 \mathrm{~min}$ for samples ozonated for 15,30 and $60 \mathrm{~min}$, while samples ozonized for 90 and 120 min required less reflux time $(30 \mathrm{~min})$. Therefore, it is evident the importance of adapting this methodology for each sample, as well as the simultaneous monitoring by auxiliary techniques, such as FTIR. Sega et al. (9) also adapted the pharmacopoeial methodology by performing reflux for $60 \mathrm{~min}$. Cirlini et al (52), used a smaller amount of sample, $0.1 \mathrm{~g}$ of ozonated sunflower oil or 0.3-0.6 g of ozonized cosmetic and added $20 \mathrm{~mL}$ of a solution of methylene chloride: glacial acetic acid $(2: 3 \mathrm{v} / \mathrm{v})$. When the sample was completely dissolved, $1 \mathrm{ml}$ of a saturated KI solution was added, then the solution was stored for $16 \mathrm{~h}$ at $25^{\circ} \mathrm{C}$ in the dark. After this time, the solution was added with $20 \mathrm{~mL}$ of distilled water and titrated.

The iodine index $\left(\mathrm{I}_{\mathrm{i}}\right)$, expressed in grams, the amount of iodine susceptible to complexation in $100 \mathrm{~g}$ of substance and is a quantitative measure of the degree of unsaturation of esterified and free fatty acids in the sample (56). This value decreases as the unsaturated groups of the oil react with the $\mathrm{O}_{3}$ is a measure of the total number of double bonds present in an oil sample, and, as the $\mathrm{O}_{3}$ reacts with the double bonds of vegetable oils, it leads to a rapid decrease in $\mathrm{I}_{\mathrm{i}}$ with increasing reaction time (50). According to Sega et al. (9), this method leads to an underestimation of the reaction of $\mathrm{O}_{3}$ with unsaturated substrates. These authors note that the behavior is different if the sample was stirred at reflux temperature, with an increase in PV after $10 \mathrm{~min}$ (accompanied by a decrease in the $\mathrm{CO}$ elongation band in FTIR). Using sesame oil, the authors reached complete titration with 180 min of reflux, this maximum time varying according to the $\mathrm{O}_{3}$ dose used in the ozonation of the oil and the estimate of the ozonation efficiency (EO) was calculated expressed as a percentage, representing the proportion of the amount of peroxidation due to ozonation using PV, to the amount of total ozone applied to the system, according to equation 2 (9):

$$
O E=\frac{\left(P V_{2}-P V_{1}\right)}{1000} \times \frac{O_{3} E}{A O D} \times 100 \text { Equation } 2
$$

Where $\mathrm{PV}_{2}$ is the value of the ozonized sample peroxide, $\mathrm{PV}_{1}$ is the value of the oil before ozonation, $\mathrm{O}_{3} \mathrm{E}$ is the equivalent weight of ozone and AOD represents the applied ozone dose (mg/g).

According to the Brazilian Pharmacopoeia (56) the iodine index can be determined using the amount of sample determined in table 2 :

Table 2. Quantity of sample to determine the iodine index.

\begin{tabular}{ll}
\hline Expected index & Sample amount $(\mathbf{g})$ \\
\hline$<20$ & 1.0 \\
$20-60$ & $0.5-0.25$ \\
$60-100$ & $0.25-0.15$ \\
$>100$ & $0.15-0.10$ \\
\hline
\end{tabular}

Then, in a $250 \mathrm{~mL}$ container, with a ground stopper, dried or washed with glacial acetic acid, introduce the sample and dissolve it in $15 \mathrm{~mL}$ of chloroform. $25 \mathrm{~mL}$ of iodine bromide solution should be added. Then, cover the container and keep it protected from light for $30 \mathrm{~min}$, shaking frequently. After adding $10 \mathrm{~mL}$ of $100 \mathrm{~g} / \mathrm{L} \mathrm{KI}$ solution and $100 \mathrm{~mL}$ of water, titrate with $0.1 \mathrm{M} \mathrm{Na}_{2} \mathrm{~S}_{2} \mathrm{O}_{3}$ stirred vigorously until the yellow color has almost disappeared. Add $5 \mathrm{~mL}$ of starch solution and continue the titration, adding $0.1 \mathrm{M}$ sodium thiosulfate, drop by drop, stirring until the total coloring disappears $\left(n_{2}\right)$. The white test must be performed under the same conditions and without the sample $\left(\mathrm{n}_{1}\right)$. Finally, the iodine index must be calculated by equation 3 :

$$
I=1,269 \times \frac{\left(n_{2}-n_{1}\right)}{M} \text { Equation } 3
$$


The acidity index, $I_{a}$, expresses, in milligrams, the amount of $\mathrm{KOH}$ required to neutralize free fatty acids in $1 \mathrm{~g}$ of sample. High levels of acidity are suggestive of marked hydrolysis of the grease constituent esters. The causes of degradation include chemical treatments that are part of the industrial processes of extraction and purification, bacterial activity, catalytic action (heat, light), inadequate storage and the presence of impurities, such as humidity, among others (56). This value increases as the unsaturated oil groups react with $\mathrm{O}_{3}(51)$.

According to the Brazilian Pharmacopoeia (56) the acidity index can be determined as follows: In a $250 \mathrm{~mL}$ round bottom flask, place approximately $10.0 \mathrm{~g}$ or exactly the prescribed amount (in $\mathrm{g}$ ) of the test substance. Add $50 \mathrm{~mL}$ of a mixture of $96 \%$ ethanol and ethyl ether (1:1) v/v. Unless otherwise indicated in the specific monograph, the solvent mixture must be previously neutralized with $0.1 \mathrm{M}$ $\mathrm{KOH}$, or $0.1 \mathrm{M} \mathrm{NaOH}$, in the presence of $0.5 \mathrm{~mL}$ of phenolphthalein solution. Heat the sample to $90{ }^{\circ} \mathrm{C}$ if necessary to dissolve it. After complete solubilization holder with $0.1 \mathrm{M} \mathrm{KOH}$ until the persistent pale pink color is observed for at least 15 seconds. Proceed to the blank test and correct the volume of titrant consumed. Calculate the $I_{a}$ according to equation 4 :

$$
I_{a}=\frac{5.610 \times n}{m} \text { Equation } 4
$$

Where: $\mathrm{n}=$ volume (in $\mathrm{mL}$ ) of $0.1 \mathrm{M} \mathrm{KOH}$ spent on titration; $\mathrm{m}=$ mass of sample in grams.

Rosado et al. (58) reported the gas chromatography coupled procedure by mass spectrometry (GC/MS) of the volatile fraction of the ozonized sunflower oil. They observed that this fraction was composed by the degradation of fatty acid ozone compounds. The ozonization of the methyl esters of sunflower oil was also monitored through infrared absorption spectroscopy (FTIR) and nuclear magnetic resonance (NMR) ${ }^{13} \mathrm{C}$ and ${ }^{1} \mathrm{H}$ (53), and thus identified reactions according to the Criegee mechanism (Figure 1).

As for infrared (IR) spectroscopy, the wave numbers that characterize the elongation of the double bond, $\mathrm{C}=\mathrm{C}$ of lipids $\left(1,654 \mathrm{~cm}^{-1}\right)$ and the $\mathrm{C}-\mathrm{H}\left(3,009 \mathrm{~cm}^{-1}\right)$ elongation are identified, as well as the elongation of ozone CO (at 1,105 $\mathrm{cm}^{-1}$ ) in the regions of unsaturated fatty acid (59).

NMR is a very useful technique for monitoring the reactions of ozone with unsaturated fatty acids present in oils. It is known that the fatty acid intensities of olefinic proton signals decrease with increasing ozone concentration, in addition to the characteristic signs of ozonides appearing in the spectra (60). The signs of interest in the NMR of untreated oil refer to the formation of 1,2,4-trioxolane rings by attack of $\mathrm{O}_{3}$ in the carbon-carbon double bonds (Figure 1), as shown by signs in 5.11-5.08 (protons of the ring carbons), in 1.63 ( $\alpha$ protons of the methylene of the carbon ring) and at $1.35 \mathrm{ppm}$ ( $\alpha$ protons of the methylene of the carbon ring). These signals are generally increased during the ozonation process while the proton signals are $5.29(\mathrm{CH}$ $=\mathrm{CH}), 2.72\left(\mathrm{C}=\mathrm{C}-\mathrm{CH}_{2}-\mathrm{C}=\mathrm{C}\right)$ and $2.03-1.96 \mathrm{ppm}\left(\mathrm{CH}_{2}\right.$ - $\mathrm{C}=\mathrm{C}-\mathrm{CH}_{2}$ and $\mathrm{CH}_{2}-\mathrm{C}=\mathrm{C}-\mathrm{C}-\mathrm{C}=\mathrm{C}-\mathrm{CH}_{2}$ decrease (9). These authors evidenced the disappearance of $\mathrm{CH}=\mathrm{CH}$ and $\mathrm{CH}_{2}$ protons $-\mathrm{CH}=\mathrm{CH}-\mathrm{CH}_{2}$ following first-order kinetics as well as the appearance of signals due to the $\alpha$ and $\beta$ protons of methylene and the 1,2,4-trioxolane of carbon rings, which also showed, by linear regression analysis, that the rate of disappearance of unsaturation and ozone formation rates are almost equal, confirming that the main reaction product is represented by ozonates and ozone fission is minimal.

As shown in Table 1, most of the works use medicinal grade $\mathrm{O}_{2}$ in the ozonation of oils, corona discharge system and generally employ sunflower, sesame and olive oil. The most used techniques for characterizing the ozonation process are the PV, which increases with the peroxidation of the oils, the $I_{i}$, which represents the proportion of unsaturated groups, whose values decrease with ozonation, the viscosity of the oils, which increases with the formation polymeric peroxides. The FTI spectrum is also used to monitor the ozonation process, identifying the decrease in the $\mathrm{C}=\mathrm{C}$ stretch bands and the NMR spectra, which detect ozone formation, among other groups. Among studies of antimicrobial activity $(43,45,47)$, studies report gram positive and gram negative strains, with increased activity as the oil is ozonated, but activity against $C$. acne has not been reported. A few number of articles reported satisfactory stability for 6 months of the ozonated oil cooled or kept at room temperature (46) and one year at fridge or a freezer (55). Moureu et al. (55) argued about the bioactivity of the nonanoic and azelaic acids formed as secondary metabolites of oxidation of aldehydes, from the decomposition of ozonides and unsaturated fatty acids present in the medium. These compounds are probably responsible for maintaining the antibacterial activity of the degraded formulations.

\section{Conclusions}

Most of the articles surveyed reported the use of the corona discharge system in the ozonation of oils, among which the most used were the sunflower, sesame and olive. Among the techniques for characterizing the ozonation process, the peroxide, acidity and iodine and viscoity indices are highlighted. The NMR technique would be the most sensitive, accurate and precise in determining the ozonation level, however it is probably not used due to at its high cost and less accessibility. Although there are reports of the use of ozonized oils in the treatment of acne in the literature and the increase in this practice in aesthetic treatments, based on studies of the antimicrobial activity of these products, there is not enough scientific evidence to support this application, as well as a lack of activity studies against $C$. acnes and stability for ozonated oils. Finally, this work highlighted the necessity of more stability studies, due to the scarcity of these studies and the apparent instability of theses formulations.

\section{Acknowledgments}

Authors thanks to CNPq for the grant of PIBIC to G.O. 


\section{Conflict of interest}

None to declare.

\section{References}

1.Smith NL, Wilson AL, Gandhi J, Vatsia S, Khan SA. Ozone therapy: an overview of pharmacodynamics, current research, and clinical utility. Med Gas Res. 2017;7(3):212-219. Available from https://doi.org/10.4103/2045-9912.215752.

2.Paula L, Silva JLM, Faria DP. Tratamentos alternativos para onicomicose: ondas d e alta frequência e laser. Rev Uniara. 2012;15(2): 68-80.

3.Râmaga Pró Estética. Available from: http://www.ramagaproestetica.com.br/2020/03/09/ozoni oterapia-e-seus-beneficios/. Acess in: 30 set. 2020.

4.Mahto A. Acne vulgaris. Medicine. 2017;45(6):386-389.

5.Figueiredo A, Massa A, Picoto A, Soare AP, Basto AS et al. Avaliação e tratamento do doente com acne - Parte I Epidemiologia, etiopatogenia, clínica, classificação, impacto psicossocial, mitos e realidades, diagnóstico diferencial e estudos complementares. Rev Port Clin Geral. 2011; 27(1): 59-65.

6.Rensi AMV, Navarro BCA, Andreani G, Zangaro RA, Kozusny-Andreani DI, Lima JC. Avaliação do efeito de óleos ozonizados de girassol e coco no controle Propionibacterium acnes. In: XXIV Congresso Brasileiro de Engenharia Biomédica - CBEB. 2014. Available from http://www.canal6.com.br/cbeb/2014/artigos/cbeb2014_ submission_347.pdf.

7.Kenneth AA. Manual of dermatologic therapeutic. 5th ed. Boston: Spiral. 1995.

8.Travagli V, Zanardi I, Bocci V. Topical applications of ozone and ozonated oils as anti-infective agents: an insight into the patent claims. Recent Pat Antiinfect. Drug Discov. 2009;4(2):130-142. Available from https://doi.org/10.2174/157489109788490271.

9.Sega A, Zanardi L, Chiasserini L, Gabbrielli A, Bocci V, Travagli V. Properties of sesame oil by detailed $1 \mathrm{H}$ and 13C NMR assignments before and after ozonation and their correlation with iodine value, peroxide value, and viscosity measurements. Chem. Phys. Lipids. 2010;163(2):148-156. Available from https://doi.org/10.1016/j.chemphyslip.2019.10.010.

10.Dagnelie MA, Montassier E, Khammari A, Mounier C, Corvec S, Dréno B. Inflammatory skin is associated with changes in the skin microbiota composition on the back of severe acne patients. Experim Dermatol. 2019;28: 961-967.

11.Zaenglein AL, Graber EM, Thibouto EM.. Acne vulgaris and acneiform eruptions. In: Goldsmith LA et al. Eds Fitzpatrick's Dermatology in General Medicine. 8th ed. Nova York: NY: Mc Graw-Hill;2012.

12.Rivitti EA. Dermatologia de Sampaio e Rivitti. São Paulo: Artes Médicas, 2018.

13.Paschoal FM, Ismael APPB. A ação da luz no tratamento da acne vulgar. Surg Cosmet Dermatol. 2010;2(2):117123.
14.Drenó B, BetToli V, Araviiskaia E, Vieira MS, Bouloc A. The influence of exposome on acne. J Eur Acad Dermatolo Venereol. 2018;32:812-819.

15. Youn SW, Park ES, Lee DH, Huh CH, Park KC. Does excretion of facial sebum really affect the development of acne? Brit J Dermatol. 2005;153:919-924.

16.Ottaviani H, Alestas T, Flori E, Mastrofrancesco A, Zouboulis CC, Picardo M. Peroxidated squalene induces the production of inflammatory mediators in HaCaT keratinocytes: a possible role in acne vulgaris. J Invest Dermatol. 2006;126(11):2430-2437. Available from https://doi.org/10.1038/sj.jid.5700434.

17.Kong $\mathrm{HH}$, Oh J, Deming C, Conlan S, Grice EA, Beatson MA. Temporal shifts in the skin microbiome associated with disease flares and treatment in children with atopic dermatites. Gen Res. 2012;22(5):850-859. Available from https://doi.org/10.1101/gr.131029.111.

18.Azulay DA, Azulay RD. Acne e doenças afins. In: Azulay DA, Azulay RD. Dermatologia. 3 ed. Rio de Janeiro: Guanabara Koogan. 2004.326-329.

19.Molina MTC. Patogenia del acné. Rev Chil Dermatol. 1996;12(3): 163-6.

20.Kim J, Ochoa MT, Krutzik SR, Takeuchi O, Uematsu $\mathrm{S}$, Legaspi AJ et al. Activation of toll-like receptor 2 in acne triggers inflammatory cytokine responses. J immunol. 2002;169(3).1535-1541. Available from https://doi.org/10.4049/jimmunol.169.3.1535.

21.Danby FW. Diet and acne. Clin Dermatol 2008; 26: $93-$ 96.

22.Elvis AM, Ekta JS. Ozone therapy: A clinical review. J Nat Sci Bio Med. 2011;2:66-70.

23.Zanardi I, Borrelli E, Valacchi G, Travagli V, Bocci V. Ozone: a multifaceted molecule with unexpected therapeutic activity. Curr Med Chem. 2016;23(4): 304314. DOI: $10.2174 / 0929867323666151221150420$.

24.Bocci V. Autohaemotherapy after treatment of blood with ozone. A reappraisal. J Int Med Res. 1994;22: 131144.

25.Bocci V, Zanardi L, Travagli V. Ozonization of human HIV-infected plasmas for producing a global vaccine. 2010;1:215-217. Available from https://doi.org/10.4161/viru.1.3.11830.

26.Inal M, Dokumacioglu A, Özcelik E, Ucar O. The effects of ozone therapy and coenzyme Q10 combination on oxidative stress markers in healthy subjects. Irish J Med Sci. 2011;180(3): 703-707.

27.Kushmakov R, Gandhi J, Seyam O, Jiang W, Joshi G, Smith NL, Ali Khan S. Ozone therapy for diabetic foot. Med Gas Res. 2018 Jul-Sep; 8(3):111-115. Available from https://doi.org/10.4103/2045-9912.241076.

28.Kim HS, Noh SU, Han YW, Kim KM, Kang H, Kim HO, Park YM. therapeutic effects of topical application of ozone on acute cutaneous wound healing. J Korean Med Sci. 2009;24(3):368-74. Available from https://doi.org/10.3346/jkms.2009.24.3.368.

29.Kataoka H, Semma M, Sakazaki H, Nakamuro K, Yamamoto T, Hirota S, Tazuya-Murayama K e Ichikawa A. Proinflammatory event of ozonized olive oil in mice. Ozone: Science \& Engineering. 
2009;31:238-246. Available from https://doi.org/10.1080/01919510902839022.

30.Bocci V. Ozone: a new medical drug. $1^{\text {a }}$ ed., ed. Springer, 2005.

31.Viebahn-Hänsler R, Fernández OSL, Fahmy Z. Ozone in medicine: the low-dose ozone concept-guidelines and treatment strategies. $\mathrm{J}$ internat ozone associat. 2012;34(6):408-424. Available from https://doi.org/10.1080/01919512.2012.717847.

32.Zeng J; Lu J. Mechanisms of action involved in ozonetherapy in skin diseases. Int. Immunopharmacol. 2018;56:235-241.

33.Gloor M, Lipphardt BA. Studies on ozone therapy of acne vulgaris. Z Hautkr. 1976;51(3):97-101.

34.Nikulin NK, Bitkina OA, Philippova LI, Kopytova TV. Dynamics of lipid peroxidation indices under influence of ozone therapy in patients with complicated forms of rosácea and acne disease. IOA 17 th World Ozone Congress. - Strasbourg. 2005.

35.Teodoro GA, Leite MN, Malaman TAB, Leite SN. Efeitos da alta frequência no tratamento da acne vulgar em adolescentes. Fisioter Bras. 2016;17(3):214-20.

36.Gonçalves VP, Patrício M. Abordagem fisioterapêutica na mulher adulta com acne. Cadernos Acadêmicos, Palhoça, SC. 2014;6(1):128-133.

37.Davis VG. Clinical Improvement of severe chronic acne conglobata. case report. Rev Esp Ozonoterap. 2018;8(1): 109-115.

38.Nogales CG, Ferrari PH, Kantorovick EO, Marques JLL. Ozone Therapy in Medicine and Dentistry. J Contemp Dent Prac. 2008;9(4)75-84.

39.Bocci V. Scientific and Medical Aspects of Ozone Therapy. Archives of Medical Research. 2006;37:425435.

40.Chagas LH, Mira A. Efeito do óleo ozonizado em lesões cutâneas em ratos. Revista Cultivando o Saber. 2015; Edição Especial: 168-181.

41.Criegee, R.; Angew. Chem., Int. Ed. 1975, 14, 745

42.Bailey P. Ozonolysis of Olefins: Introduction, Initial Ozone Attack and Adduct; The Peroxides Products. In: Ozonização em química orgânica. 1 ed. Nova York: Academic Press, 1978, p.7-8.

43. Valacchi G, Lim Y, Belmonte G, Miracco C, Zanardi I, Bocci V, Travagli V. Ozonated sesame oil enhances cutaneous wound healing in SKH1 mice. J Tissue Repair Regen. 2010; 19(1):107-115. Available from https://doi.org/10.1111/j.1524-475X.2010.00649.x.

44.Travagli V, Zanardi I, Valacchi G, Bocci V. Ozone and ozonated oils in skin diseases: a review. Mediat Inflamm. 2010; Article ID 610418:1-9. Available from https://doi.org/10.1155/2010/610418.

45.Pryor WA, Das B, Church DF. The ozonation of unsaturated fatty acids: aldehydes and hydrogen peroxide as products and possible mediators of ozone toxicity. Chem Res Toxicol. 1991;4:341-348.

46.Hernández R, Martínez G, Díaz M. Aspectos químico físicos del aceite de girasol ozonizado. Rev. CENIC Ciência Quím. 2004;35:159-162.

47.Nourooz-Zadeh J, Tajaddini-Sarmadi J, Wolf SP. Measurement of hydroperoxides in edible oils using the ferrous oxidation in xylenol orange assay. J Agric Food Chem. 1995;43(1):17-21. Available from https://doi.org/10.1021/jf00049a005.

48.Kamm W, Dionisi F, Bay LB, Hischenhuber C, Schamarr HG, Engel KH. Analysis of steryl esters in cocoa butter by on-line liquid chromatography-gas chromatography. J Chromatogr A. 2001;918(2):341349. Available from https://doi.org/10.1016/s00219673(01)00755-5.

49.Díaz MF, Hernandez R, Martinez G, Vidal G, Gomez M, Fernandez H, Garcés R. Comparative study of ozonized olive oil and ozonized sunflower oil. J Braz Chem Soc. 2006;17(2):403-407.

50.Zanardi I, Travagli V, Gabbrielli A, Chiasserini L, Bocci V. Physico-chemical characterization of sesame oil derivatives. Lipids. 2008;43:877-886. Available from https://doi.org/10.1007/s11745-008-3218-x.

51.Díaz MF, Sánchez Y, Gomez MFD, Fernandez F, Veloso MCC, Pereira PAP, Mangrich AS, Andrade JB. Physicochemical characteristics of ozonated sunflower oils obtained by different procedures. Grasas Y Aceites. 2012;63:466-474.

52.Cirlini M, Caligiani A, Palla G, De Ascentiis A, Tortini P. Stability studies of ozonized sunflower oil and enriched cosmetics with a dedicated peroxide value determination. Ozone: Sci. Eng. 2012;34:293-299.

53.Kogawa NRA et al. Synthesis, Characterization, termal behavior, and biological activity of ozonides from vegetable oils. Royal Soc Chem. 2015;5:65427-65436. Available from https://doi.org/10.1039/c5ra02798e.

54.Varol K, Koc AN, Atalay MA, Keles I. Antifungal activity of olive oil and ozonated olive oil against Candida spp. and Saprochaete spp. Ozone: Sci Eng. 2017;39(6):462-470. Available from https://doi.org/10.1080/01919512.2017.1322490.

55.Moureu S, Violleau F, Haimoud-Lekhal DA, Calmon A. Influence of Storage Temperature on the Composition and the Antibacterial Activity of Ozonized Sunflower Oil Ozone: Science \& Engineering, 2016;38:2,143-149. Available from https://doi.org/10.1080/01919512.2015.1128319.

56.Farmacopeia Brasileira. 6. Ed., Brasília: Agência Nacional de Vigilância Sanitária, 2019.

57.European pharmacopoeia. 5th edn. Strasbourg: Council of Europe, 2004.

58.Rosado A, Moleiro J, Hernandez C, Jardines D. Volatile components of ozonized sunflower oil "oleozon". Ozone: Sci Eng. 2001;23(2):121-126. Available from https://doi.org/0.1080/01919510108961994.

59.Soriano Jr. NU, Migo VU, Matsumura M. Ozonation of sunflower oil: Spectroscopic monitoring of the degree of unsaturation. J Am Oil Chem Societ. 2003;80(10):997-1001. Available from https://doi.org/1007/s11746-003-0810-1

60. Vlachos N, Skopelitis Y, Psaroudaki M, Konstantinidou V, Chatzilazarou A, Tegou E. Applications of fourier transform - infrared spectroscopy to edible oils. Anal Chim Acta. 2006; 573-574:459-65. Available from https://doi.org/10.1016/j.aca.2006.05.034. 